\title{
低用量アスピリンによる大腸発がん予防
}

宮本真吾, 石川秀樹, 若林敬二, 酒井敏行, 武藤倫弘 ${ }^{*}$

\section{Chemopreventive effects of low-dose aspirin on colorectal carcinogenesis}

Shingo MiYAmoto, Hideki IshIKaWA, Keiji WAKABAYASHI, Toshiyuki

SAKAI, Michihiro MUTOH

要約：症例対照研究やコホート研究ではアスピリンの常用者は大腸がんの発 生頻度が低いことが多数報告されている。ランダム化比較試験においても, アスピリンは大腸がんの前がん病変である腺腫の発生を予防することがメ夕 解析レベルで示されている。 大腸がんに関しては，これまで明らかではな かったが，アスピリン介入試験の終了後，長期間追跡すると大腸がんの発生 を抑制することが示された，以上は欧米のデータであるが，日本でもアスピ

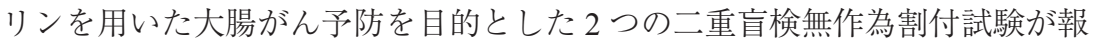
告されており，現在ではアスピリンの実用化に向け，最適化に関する大規模 試験が行われている，本稿では，アスピリンの大腸がん予防介入試験の現状 を紹介するとともに，アスピリンの標的として可能性のある血小板と大腸 がんとの関連性について考察する。

Key words: aspirin, chemoprevention, colorectal cancer, cyclooxygenase, platelet

\section{1. アスピリンの大腸がん予防介入試験}

Kune $ら^{1)}$ の症例対照研究により, アスピリン服用 者の大腸がん発生率が $40 \%$ 減少していることが 1988 年に報告されてから，大腸がんに対するアス ピリンの抑制効果に関する多くの研究がなされた. Flossmann $ら^{2)}$ は, 19 の症例対照研究のメ夕解析を 行い,アスピリンやNSAIDsを使用しなかった群と 比べて，使用したことのある群では大腸がん罹患に 関するオッズ比 $(\mathrm{OR})$ は 0.80[95\% 信頼区間 (95\% CI）：0.73-0.87]であり，用量・服用期間依存的に有 意に低下することを示した。

\footnotetext{
*責任者連絡先

国立研究開発法人国立がん研究センターがん予防・検診 研究センター予防研究部

干 104-0045 東京都中央区築地 5-1-1

Tel: 03-3542-2511, Fax: 03-3543-9305

E-mail: mimutoh@ncc.go.jp
}

コホート研究についても多くの検討がなされてい るが，2008 年にChan ら $^{3)}$ が行った医療関係の男性 約 5 万人に対するコホート研究において, アスピ リンや非ステロイド性抗炎症薬 (NSAIDs) 常用者は, 非常用者と比べて大腸がん罹患に関する相対危険度 (RR)は 0.79 (95\%CI: 0.70-0.90) と有意に低く，その 服用期間に依存していた。

最もエビデンスの高い研究方法は二重盲検法によ る無作為割付臨床試験であるが，健常者の大腸がん の発生をエンドポイントとすると臨床試験には膨大 な参加者数と長期間の介入が必要であるため, 現実 的ではない。一般的に，大腸がん化学予防剂の想定 服用者は健常者よりも大腸がんのリスク保有者とな ると考えられるため, 大腸がん予防介入試験では, 大腸がんの高危険度群である家族性大腸腺腫症 (FAP) や Lynch 症候群，大腸腺腫や大腸がんの既往 者などが対象となり, 多くの場合, 大腸がんの前がん 病変である大腸腺腫の発生をエンドポイントとした 
臨床試験が行われている。

BurnらはFAP患者を対象としたアスピリンの二 重盲検無作為割付臨床試験 (CAPP1)を行った ${ }^{4)}$ 。こ の臨床試験では若年の FAP 患者 (10〜21 歳)にアス ピリン $(600 \mathrm{mg} /$ 日)を 1 ～12 年投与し, 腸ポリープ数 の減少傾向を認めている。われわれも FAP を対象と したアスピリンの二重盲検無作為割付臨床介入試験 (J-FAPP Study II) を行い, われわれは 35 人のFAP 患者に対して，低用量アスピリン $(100 \mathrm{mg} /$ 日 $)$ と偽薬 を 6〜10 カ月間投与した。 主解析であるポリープ減 少をアスピリンの相対有効率として計測すると 2.33 (95\%CI：0.72-7.55) と多い傾向が認められた。また, 小さなポリープ(アスピリン投与前の平均腫瘍径が $2 \mathrm{~mm}$ 未満)を対象としたサブ解析を行うと, 投与後 の腫瘍径は有意に縮小していることがわかった ${ }^{5)}$.

大腸腺腫や大腸がんの既往者に対するアスピリン の二重盲検無作為割付臨床介入試験は, 欧米で $4 \supset$ 報告されており，このメ夕解析結果が Coleらによ り報告されている ${ }^{6}$. 主解析として新たな大腸腺腫 の発生の有無を解析し, サブ解析として advanced lesion(絨毛成分あり, 直径 $1 \mathrm{~cm}$ 以上, 腺腫内がん や浸潤がん)や有害事象の発生の有無を解析してい る。その結果，アスピリンは腺腫で $88 \%$, advanced lesion で $72 \%$ とそれらの発生を有意に抑制している ことが明らかとなった。 日本人を含む東洋人を対象 とした大腸腺腫や大腸がんの既往者に対するアスピ リンの二重盲検無作為割付臨床介入試験はこれまで 報告されていなかったため, われわれは大腸腫瘍患 者に対して低用量アスピリン腸溶錠 (100 mg/日)を 2 年間投与する多施設二重盲検無作為割付臨床試験 (J-CAPP study) を行った ${ }^{7)}$. 主解析を投与 2 年後の 大腸腫瘍の発生の有無としたが, アスピリン群 152 人中 96 人, プラシーボ群 159 人中 86 人は 2 年間に 大腸腫瘍の発生を認めなかった。年齢, 性, エント リー前の大腸腫瘍数で補正した ORは $0.60(95 \% \mathrm{CI}$ ： 0.36-0.98）となり, 東洋人においてもアスピリンは 大腸腫瘍の発生を有意に抑制することがわかった。 興味深いのは，J-CAPP studyにおいて喫煙の有無で 層別化すると，現在非契煙者(禁煙者を含む)では $\mathrm{OR}=0.37$ (95\% CI：0.21-0.68) であり，より強力にア スピリンは大腸腫瘍の発生を抑制したが, 現在喫煙 者の ORは3.44(95\%CI：1.12-10.64）と逆に増加し
たことである。喫煙との逆相関関係は，まだわれわ れの報告のみであるので, より正確な評価を得るた めには今後の追試の結果を待つ必要がある.

アスピリンは心疾患予防のための無作為割付試験 が複数行われているので，これらの試験から大腸 がん罹患へのアスピリンの影響を解析することがで きる. 2010 年に Rothwell ら $^{8}$ が報告した 5 つの臨床 試験の 20 年間の追跡データの解析結果によると, アスピリンは投与量に依存しないが長期投与によっ て大腸がん死亡を $\mathrm{OR}=0.66(95 \% \mathrm{CI}: 0.51-0.85)$ と有 意に減少することがわかった。ここでは，アスピ リンの大腸がん予防効果は, 近位大腸(盲腸から横 行結腸)において強いことが示された。ささらに2011 年には 8 つの臨床試験の結果を合わせて解析してい るが, 大腸がん以外にも胃がん, 食道腺がん, 肺がん などでもアスピリンは，がんの発生を予防してい る ${ }^{9)}$. 動物実験でも示されているが，アスピリン等 の NSAIDs は腺がんに対してより強い抑制効果を示 すことがその特徵として挙げられると考えられる。

今後, アスピリンを臨床で実際に用いるために は，アスピリンの有効性が高く，副作用が少ない服 用対象者の絞り达みを行う必要がある。例えば遺伝 子多型調査, 投与量や投与方法, その他の薬剤(がん 化学予防剂など) との組み合わせなどの最適化研究 が必要である。これらの問題点を考慮し, 北デン マークで大腸がんと診断された患者 $(10,280$ 症例数 $)$ を対象に最近, 研究が行われたが, 5 年以上の長期 の連続的な低用量アスピリンの使用が大腸がんリス クを減少するのに有効であると報告されている ${ }^{10)}$. わが国においても，これらの課題の克服のため，国 立研究開発法人日本医療研究開発機構 (AMED) 戦略 推進部がん研究課の委託業務(題目「がん化学予防薬 の実用化をめざした大規模臨床試験」および「大腸 がん超高危険度群におけるがんリスク低減手法の最 適化に関する研究」)にて, 現在, 研究が行われてい る.

\section{2. 血小板と悪性腫瘍}

血小板は組織損傷時に重要な役割を担い, 止血作 用に加え，とくに損傷治癒時の炎症反応との関連が 示唆されている. そして, 血小板のこの生理的な役 
割が破綻すると様々な病態に結びつくことが想定さ れている，例えば，1968 年に報告された血小板数 とがん転移との関連が挙げられる ${ }^{11)}$ 。腫瘍随伴症と して血小板増多はがん患者の 10～57\%に認められ るが(2), tumor cell-induced platelet aggregation(TCIPA) が，がん細胞増殖とその転移に重要な役割を担って いると考えられている ${ }^{13)}$ ，又，血小板は生理活性物 質の放出を促進し，血管新生と細胞増殖を促進する と考えられている，既存の血管より新しい血管が形 成される血管新生は, 生理的な状態では創傷治癒な どにおいてのみ観察されるが，がんにおいては病的 血管新生が多く発生している。腫瘍血管新生は, 腫 瘍本体へ酸素や栄養を供給し，腫瘍を増殖させる役 割を担っているが, さらに腫瘍転移にも直結してい る。血管新生関連因子としては, $\alpha$ 顆粒内の因子(線 維芽細胞成長因子 (FGF)，インスリン様増殖因子 (IGF)，血管内皮細胞成長因子 (VEGF)，血小板由来 成長因子 (PDGF) ) やペルオキシソーム内にある血小 板活性化因子などが挙げられている ${ }^{13)}$ ，濃染顆粒内 にある，主に血小板の cyclooxygenase (COX)-1より 産生されるトロンボキサン $(\mathrm{TX}) \mathrm{A}_{2}$ やアデノシン二 リン酸も血管新生とがん転移に重要なプレイヤーで あることがわかってきた ${ }^{13)}$ ．がん細胞増殖因子とし ては COX-2 を誘導するインターロイキン (IL) - $1 \beta$ が 血小板より放出される ${ }^{14,15)}$ ので，血小板活性を抑制 できれば腫瘍の進展を抑制できると期待されている.

\section{3. 低用量アスピリンの抗血小板作用と大腸発 がん抑制作用}

アスピリンの薬物動態に着目すると, 低用量アス ピリンの大腸発がんにおける標的臓器／細胞は主に 血小板である可能性がある。なぜならば，血小板で は COX-1のみ発現しており, COX-2よりも COX-1 に選択阻害性を持つアスピリンは，低用量では COX-1 (530 番のセリン残基)を標的とするからであ る。そして他の核のある細胞では低用量アスピリン により COX-2 が不活化されてもそれを補うべく，す ぐにCOX-2 を誘導し，低用量アスピリンは効果をほ とんど示せないと思われる。そもそも低用量アスピ リンの血中濃度は低く，作用時間は短い。 $75 \mathrm{mg}$ /日 のアスピリンの服用によりアスピリンの血中濃度は,
約 $7 \mu \mathrm{M}$ と低く推定されている ${ }^{16)} .100 \sim 300 \mathrm{mg}$ /日 アスピリン腸溶錠を服用した場合，末梢血中にアス ピリンを測定できない濃度でも血小板凝集は阻害さ れることも知られている 謝物 (サリチル酸およびその代謝物) はいずれも抗血 小板作用を持たない(代謝物のゲンチジン酸は解熱 鎮痛作用を持つ)ので，その他の影響を与える因子 である代謝物の影響は考えなくて良いと思われ る18)。血中アスピリンのほとんど(80〜90\%)はすぐ に血漿蛋白質と結合するため, アスピリンの血中滞 在時間は短い。そのため, アスピリンの全身循環中 における作用は小さいと思われるが，血中での血小 板の寿命は 7〜10日あるため, アスピリンの主な ターゲットが血小板であるならば，十分にその効果 を発揮する可能性がある。実際，75〜100 mg/日の アスピリンの服用により血中の $\mathrm{TXB}_{2}$ 值がほぼゼロ となることは低用量アスピリンが有効に抗血小板作 用を持つことを示している ${ }^{19)}$.

大腸がん患者においても FAP の患者においても 血小板が活性化していることが報告されている $か^{20,21)}$, これまでの研究により大腸腺腫の段階では, COX-1 よりも間質細胞やマクロファージ細胞におけ る COX-2 の活性化が重要であると考えられている. 腺腫の異型度が増すにつれ，上皮細胞における COX-2 の活性化が重要であると考えられており，発 がん過程の時期により重要性を担う細胞が異なるの は興味深いが，何れにしてもプロスタグランジン (PG)が大腸発がんのキープレイヤーであることは確 実と思われる。 $A p c$ 遺伝子が变異しており，腸管に 多数のポリープを生じる Min マウスの COX-1 や $C O X-2$ 遺伝子を欠損させた検討においては，両マウ スとも腸ポリープの生成を $90 \%$ にまで抑制し，サブ タイプに関わらず COX が重要であるというデータ が出ている22)。われわれの検討においても COXの 産物である $\mathrm{PGE}_{2}$ の投与がラット大腸がんを促進し, COX-1 選択的阻害剂のみでも十分にマウス大腸発 がんを抑制するというデー夕を得ている ${ }^{23,24)}$ ，前段 落で述べた様に血小板の COX-1 の主な産物である $\mathrm{TXA}_{2}$ は，発がん促進に寄与していると考えられる。 一方， $\mathrm{TXA}_{2}$ の受容体を欠損したマウスでは前がん 病変である大腸異常陰窩巣 $(\mathrm{ACF})$ の生成が減少しな かった ${ }^{25)}$ ，今後， $\mathrm{TXA}_{2}$ が発がんのどのステージに関 
与するかについて検討することは重要と思われる.

\section{4. おわりに(大腸がん予防研究への期待)}

本稿で取り上げたアスピリンを用いた多くのがん 予防臨床介入試験の報告においては，血小板の活性 に関する記載は極めて限られているが，今後アスピ リンの血小板活性抑制作用が発がん抑制に関与する かの検討は, 臨床介入試験においても重要なポイン トになってくると思われる，更なる基礎研究からの エビデンスの蓄積が望まれる。

われわれの検討では，環境要因である夕バコがア スピリンの大腸腫瘍再発抑制作用をキャンセルする 結果を得ているが, その他, アスピリンの抗血小板 活性を減弱させるようなイブプロフェンや薬剤誘発 性の血小板の変化を回復させるエピネフリンなど, 多くの環境因子がアスピリンの作用を修飾すると考 えられる。それら交絡因子の研究もこれから進める 必要があると思われる。ささらに，アスピリン抵抗性 の影響も今後注意深くデータを取って行く必要があ る.

アスピリンは 100 年以上もの臨床実績があり, 副 作用もよくわかっている薬剤である。消化管出血や 出血性脳卒中という重篤な副作用があることも知ら れているが，血管内皮細胞の COX-2 より主に産生 される $\mathrm{PGI}_{2}$ の抑制が選択的 COX-2 阻害剂による重 篤な心血管障害の原因であることを鑑みると，低用 量アスピリンは現時点では最有力の大腸がん化学予 防剤の候補であることが，その副作用機序の側面か らも強く示唆される.

著者全員の利益相反 (COI)の開示 :

本論文発表内容に関連して開示すべき企業との利益 相反なし.

\section{文献}

1) Kune GA, Kune S, Watson LF: Colorectal cancer risk, chronic illnesses, operations, and medications: case control results from the Melbourne Colorectal Cancer Study. Cancer Res 48: 4399-4404, 1988.

2) Flossmann E, Rothwell PM; British Doctors Aspirin Trial and the UK-TIA Aspirin Trial: Effect of aspirin on long-term risk of colorectal cancer: consistent evidence from randomised and observational studies. Lancet 369: 1603-1613, 2007.
3) Chan AT, Giovannucci EL, Meyerhardt JA, Schernhammer ES, Wu K, Fuchs CS: Aspirin dose and duration of use and risk of colorectal cancer in men. Gastroenterology 134: 21 $28,2008$.

4) Burn J, Bishop DT, Chapman PD, Elliott F, Bertario L, Dunlop MG, Eccles D, Ellis A, Evans DG, Fodde R, Maher ER, Möslein G, Vasen HF, Coaker J, Phillips RK, Bülow S, Mathers JC; International CAPP consortium: A randomized placebo-controlled prevention trial of aspirin and/or resistant starch in young people with familial adenomatous polyposis. Cancer Prev Res 4: 655-665, 2011.

5) Ishikawa H, Wakabayashi K, Suzuki S, Mutoh M, Hirata K, Nakamura T, Takeyama I, Kawano A, Gondo N, Abe T, Tokudome S, Goto C, Matsuura N, Sakai T: Preventive effects of low-dose aspirin on colorectal adenoma growth in patients with familial adenomatous polyposis: double-blind, randomized clinical trial. Cancer Med 2: 50-56, 2013.

6) Cole BF, Logan RF, Halabi S, Benamouzig R, Sandler RS, Grainge MJ, Chaussade S, Baron JA: Aspirin for the chemoprevention of colorectal adenomas: meta-analysis of the randomized trials. J Natl Cancer Inst 101: 256-266, 2009.

7) Ishikawa H, Mutoh M, Suzuki S, Tokudome S, Saida Y, Abe T, Okamura S, Tajika M, Joh T, Tanaka S, Kudo SE, Matsuda T, Iimuro M, Yukawa T, Takayama T, Sato Y, Lee K, Kitamura S, Mizuno M, Sano Y, Gondo N, Sugimoto K, Kusunoki M, Goto C, Matsuura N, Sakai T, Wakabayashi K: The preventive effects of low-dose enteric-coated aspirin tablets on the development of colorectal tumours in Asian patients: a randomised trial. Gut 63: 1755-1759, 2014.

8) Rothwell PM, Wilson M, Elwin CE, Norrving B, Algra A, Warlow CP, Meade TW: Long-term effect of aspirin on colorectal cancer incidence and mortality: 20-year follow-up of five randomised trials. Lancet 376: 1741-1750, 2010.

9) Rothwell PM, Fowkes FG, Belch JF, Ogawa H, Warlow CP, Meade TW: Effect of daily aspirin on long-term risk of death due to cancer: analysis of individual patient data from randomised trials. Lancet 377: 31-41, 2011.

10) Friis S, Riis AH, Erichsen R, Baron JA, Sørensen HT: LowDose Aspirin or Nonsteroidal Anti-inflammatory Drug Use and Colorectal Cancer Risk: A Population-Based, Case-Control Study. Ann Intern Med 163: 347-355, 2015.

11) Gasic GJ, Gasic TB, Stewart CC: Antimetastatic effects associated with platelet reduction. Proc Natl Acad Sci USA 61: 46-52, 1968.

12) Sierko E, Wojtukiewicz MZ: Platelets and angiogenesis in malignancy. Semin Thromb Hemost 30: 95-108, 2004.

13) Goubran HA, Stakiw J, Radosevic M, Burnouf T: Platelets effects on tumor growth. Semin Oncol 41: 359-369, 2014.

14) Honn KV: Inhibition of tumor cell metastasis by modulation of the vascular prostacyclin/thromboxane A2 system. Clin Exp Metastasis 1: 103-114, 1983.

15) Grosser T, Fries S, FitzGerald GA: Biological basis for the cardiovascular consequences of COX-2 inhibition: therapeutic challenges and opportunities. J Clin Invest 116: 4-15, 2006.

16) Charman WN, Charman SA, Monkhouse DC, Frisbee SE, Lockhart EA, Weisman S, Fitzgerald GA: Biopharmaceutical 
characterisation of a low-dose $(75 \mathrm{mg})$ controlled-release aspirin formulation. Br J Clin Pharmacol 36: 470-473, 1993.

17) Lewis HD, Davis JW, Archibald DG, Steinke WE, Smitherman TC, Doherty JE, Schnaper HW, LeWinter MM, Linares E, Pouget JM, Sabharwal SC, Chesler E, DeMots H: Protective effects of aspirin against acute myocardial infarction and death in men with unstable angina. Results of a Veterans Administration Cooperative Study. N Engl J Med 309: 396-403, 1983.

18) Smith MJ: The estimation of sodium gentisate in tablets and injections. J Pharm Pharmacol 3: 439-443, 1950.

19) Patrignani P, Filabozzi P, Patrono C: Selective cumulative inhibition of platelet thromboxane production by low-dose aspirin in healthy subjects. J Clin Invest 69: 1366-1372, 1982.

20) Sciulli MG, Filabozzi P, Tacconelli S, Padovano R, Ricciotti E, Capone ML, Grana M, Carnevale V, Patrignani P: Platelet activation in patients with colorectal cancer. Prostaglandins Leukot Essent Fatty Acids 72: 79-83, 2005.

21) Dovizio M, Tacconelli S, Ricciotti E, Bruno A, Maier TJ, Anzellotti P, Di Francesco L, Sala P, Signoroni S, Bertario L, Dixon DA, Lawson JA, Steinhilber D, FitzGerald GA,
Patrignani P: Effects of celecoxib on prostanoid biosynthesis and circulating angiogenesis proteins in familial adenomatous polyposis. J Pharmacol Exp Ther 341: 242-250, 2012.

22) Chulada PC, Thompson MB, Mahler JF, Doyle CM, Gaul BW, Lee C, Tiano HF, Morham SG, Smithies O, Langenbach R: Genetic disruption of Ptgs-1, as well as Ptgs-2, reduces intestinal tumorigenesis in Min mice. Cancer Res 60, 47054708, 2000.

23) Kawamori T, Uchiya N, Sugimura T, Wakabayashi K: Enhancement of colon carcinogenesis by prostaglandin E2 administration. Carcinogenesis 24: 985-990, 2003.

24) Kitamura $T$, Kawamori $T$, Uchiya N, Itoh M, Noda $T$, Matsuura M, Sugimura T, Wakabayashi K. Inhibitory effects of mofezolac, a cyclooxygenase-1 selective inhibitor, on intestinal carcinogenesis. Carcinogenesis 23: 1463-1466, 2002.

25) Mutoh M, Watanabe K, Kitamura T, Shoji Y, Takahashi M, Kawamori T, Tani K, Kobayashi M, Maruyama T, Kobayashi K, Ohuchida S, Sugimoto Y, Narumiya S, Sugimura T, Wakabayashi K: Involvement of prostaglandin E receptor subtype EP(4) in colon carcinogenesis. Cancer Res 62: 28-32, 2002. 